\title{
Social Network Sites Usage and Fear of Missing Out among Female Instagram User
}

\author{
Eem Munawaroh* \\ Guidance and Counseling \\ Universitas Negeri Semarang \\ Semarang, Indonesia \\ eemmunawaroh@mail.unnes.ac.id*
}

\author{
Yuli Nurmalasari \\ Guidance and Counseling \\ Universitas Negeri Yogyakarta \\ Yogyakarta, Indonesia \\ yulinurmalasari@uny.ac.id
}

\author{
Afriyadi Sofyan \\ Guidance and Counseling \\ Universitas Negeri Semarang \\ Semarang, Indonesia \\ afriyadisofyan@mail.unnes.ac.id
}

\begin{abstract}
The aim of this investigation was to examine the correlation between social network sites usage and fear of missing out (FOMO) of female instagram user with age ranged from 18 to 27 . The responden involved 106 female college student of female instagram user from various university in west, east, and central java, Indonesia. The data collected randomly through an online link Google Form use 2 psychological scale, Student Form Social Media Addiction Scale (SMAS-SF) developed by Sahin and Fear of Missing Out Scale developed by Przybylski. The result show social network sites usage significantly corellate with fear of missing out of female instagram user.
\end{abstract}

Keywords-social network sites, FOMO, Instagram, female user

\section{INTRODUCTION}

Nowdays, internet is people basic need, because it fulfilled various need of life. The main purpose of using internet is for communication, work, and community enggagement. Survey of Indonesian Internet Service Providers Association (2017) on infographics of Penetration and the relationship of Indonesian Internet Users shows that from 262 million people Indonesia's total population, 54, $68 \%$ or 143.26 million people are internet users [1]. This shows an increasing in cyberspace activity by spending $79 \%$ their time accesing the internet every day [2].

An actual research published by Crowdtap, Ipsos Media CT and The Wall Street Journal in 2014 involving 839 respondents from 16 to 36 years of age showed that the number of time spend by the respondent to dive with internet and social media reached 6 hours 46 minutes per day. This number extremely exceed the activities to access traditional media such as newspaper and magazine [3]. Facebook reports that around 1 billion active users on August 27 2015, meaning 1 in 7 people in the world use Facebook to connect with friends and family.

The usage of social media such as Facebook, Twitter, YouTube, Instagram and Path as one of the communication facilities in cyberspace shows an increasing number from year to year. Research conducted by We Are Social and Hootsuite, revealed that Indonesian are one of the biggest country with high intensity of internet access especially social media. It is recorded that 130 million Indonesian people are active user in many number of social media. It can be concluded that $97.9 \%$ internet enjoyer in Indonesia are social media user it mean that approximately half of Indonesia's citizen are social media user [4].

Instagram is one of the most liked social media platforms for the young generation in 2019, Instagram has approximately 700 million active users worldwide, $60 \%$ of whom are users between the ages of 18 and 29 with a majority of women. This number is growing, especially in Asia and South America [5]. In Taiwan, the majority of Instagram users are female college students or junior high school students aged 12 to 24 years. In Indonesia, Instagram is social media with the second largest number of users after Facebook with 19.9 million users [6].

Females has proven as social media dominant users Sheldon and Bryant, gender was the biggest predictor of time spent on Instagram [5]. Pew Research Center also showed that women used the site more frequently than men with 32 and 23 percent conversely.

There are various backgrounds of the high use of Instagram in women compared to men. Huang \& Su explained that women tend to prioritize their appearance in detail, color, and attractiveness compared to men [5]. And this tendency can be facilitated by features available on Instagram, such as selfi and display it on Instagram with attractive colors and images. Women that identic with beauty found instagram as a suitable media to exhibit them selves. And this tendency can be facilitated by features available on Instagram, such as selfi and display it on Instagram with attractive colors and images. Women drive the content on Instagram and are predictably more affected by their experiences on social media networks more than men. Reseach of Raacke and Bond shown that women were more likely to engage in online communication to maintain personal relationships with friends, family and coworkers, while men were more likely to use online communication to pursue romantic or sexual interests [7].

Various research results link the use of social networking with the fear of missing out (FOMO). FOMO is a feeling of anxiety that arises because of worries of missing information. It could be describe as an intra-personal nature that makes individuals continuously update what others do on social media [8]. FOMO stems from psychological problems related to individual competence and the need to connect with others. One way to meet this need is to use social networking, because the dynamics of social applications can provide satisfactory social flow and 
information satisfaction for its users [8]. As many as $70 \%$ of millennials with an age range of 18-34 years experience FOMO, the higher the FOMO a person is, the more sticky with the use of social media [6]. FOMO is a predictor of the problem of internet and social media use [9]. The aim of this investigation was to determine the relationship between the use of social media networks and the fear of missing out on women using Instagram.

\section{METHODS}

This study involved 106 college female instagram user living in Java Island include west, east, and central java. The data collected from 18 to 27 age of respondent. The instreument delivered through Google Form. To find out the level of use of social networking sites, used Student Form Social Media Addiction Scale (SMAS-SF) developed by Sahin [10]. This scale contains 29 items divided into 4 factors, expenditure, virtual communication, virtual problem, and virtual information factors. The Social Media Addiction Scale Student Form (SMAS-SF) is answered using a Likert point rating scale of 1 to 5.1 means it is very inappropriate and 5 is very appropriate. Based on the results of sahin research (2018) the Social Media Addiction Scale Student Form (SMAS-SF) is very valid and can be relied upon to measure the use of social networking sites or Social Networking Sites.

To measure the FOMO used The Fear of Missing Out Scale developed by Przybylski et al. [11]. This scale contains 10 items aimed to measuring the level of FOMO. Examples of statement items are "I am afraid that other people will experience events that are more pleasant than mine" and "I feel anxious when I do not know how other friends feel." The scale is answered by using the 5-point likert scale starting from $1=$ incompatible and $5=$ very appropriate. Data were analyzed using Pearson correlation analysis.

\section{RESULT AND DISCUSSION}

Table 1

Correlation social network Use and Fear of Missing Out

\begin{tabular}{|l|c|c|}
\hline \multicolumn{1}{|c|}{ Variabels } & $\begin{array}{c}\text { Social Network } \\
\text { Use }\end{array}$ & FOMO \\
\hline $\begin{array}{l}\text { Social Network Use } \\
\text { correlation coefficient }\end{array}$ & 1,000 &, $573^{* *}$ \\
\hline Sig. (2-tailed) & $\cdot$ &, 000 \\
\hline $\mathrm{N}$ & 106 & 106 \\
\hline FOMO correlation coefficient &, $573^{* *}$ & 1,000 \\
\hline Sig. (2-tailed) &, 000 & $\cdot$ \\
\hline $\mathrm{N}$ & 106 & 106 \\
\hline
\end{tabular}

Table 1 provide evidence that social media addiction is positively associated with the FOMO, a Spearman correlation was conducted. A significant positive correlation emerged between social media addiction and FOMO, r (106) $=.573, \mathrm{p}<.01$.

This research in line with the findings which state that the higher the level of social media addiction, the higher the level of FOMO, to intensively check the online status of others, and update their own status as often as possible [12]. The use of the internet is no longer as needed. FOMO is one of the behavior that represent individuals who are in a state of being dissolved in accessing the internet, unable to control usage so that it adversely affects work, relationships, or other important activities.

Accessing the internet has become easier because of the of increasingly portable communication technology through tablets, smartphones, and even internet-based watches. This ease heightens the potential of the individual to experience FOMO at a high level. Through devices that are connected to the internet and are always online, individuals do not realize that they are online even though they are doing status updates on Instagram, Facebook and other social media via mobile devices. High social media addiction is also determined by the type of social media used. As expressed by Franchina et al, persons with FOMO are concluded to have a higher desire to continuously up to date with what other people are doing. FOMO positively predicted the use of the four most popular social media platforms: Facebook, Snapchat, Instagram and Youtube. FOMO appears to be the modest predictor of the most common social media platforms.

Beside of technology development, the adolescents characteristic contributes to the problem of dependence on social media and FOMO. The age range of adolescents is suspected as the dominant internet access as stated by Comscore data, internet usage among adolescents has experienced the biggest increase compared to other age ranges of $84.4 \%$ [13]. According to Orford, internet features that are often accessed by teenagers which include gambling, shopping, pornography, games, online chat can improve the condition of compulsiveness in accessing the internet that can encourage a person to repeat accessing the internet [14]. Referring to Orford, the availability and ease of accessing the internet, is a factor that can increase the likelihood of individuals getting emotional satisfaction, then the repetition or sustainability characteristics increase the likelihood of students to maintain internet access behavior.

Positive relationship between social network site usage and FOMO on female instagram user has several reason. Female easily use instagram when they are in awkward situation as reported by Yi Tang and Seng Fang [5]. Whenever individuals feel boring or inconvenience, they will open instagram and play with it. Furthermore, high intensity usage of this newest applicaion related to beauty ideal and appearance comparisons on [15]. Through edit and filter tools provided by instagram before uploaded it, female can create a picture of themselves that close to the standard of beauty they hold. As a result, they feel more beautiful then they was or compare to their peers. This second reason make them have higher intensity to keep in touch with instagram.

Besides as self expression platform, instagram also widely use in business especially by women. Waaly and Koshi on their exploratory study about instagram as marketing tool found that instagram mostly use for homebased business to build brand awareness and customer attachment [16]. In addition, security is another main reason for female using instagram in their business since they have 
no need to meet stranger especially opposite sex to do transaction.

FOMO is also highly connected with selfpresentation of female in using this favored social media. Self-presentation is the action of picture aploaded to show themselves related to physic appearance and relationship. This phenomenon represented by muslim women in instagram through using variety of hijab [17].

Related to female user dependency on accessing instagram as a social network sites, the concept of internet addiction by Griffith represent certain characteristics of internet addiction, include: salience, mood modification, tolerance, withdrawal, relapse, and conflict [18]. Salience defined by preoccupied with their level of dependency to internet, including cognitive, emotional, and behavior aspect. Individuals with internet addiction may constantly being force and has willingness to access the Internet, then logging on to their account on social media, and neglect to have social interactions in the real life.

Mood modification define behavior of accessing internet in order to overcome depressed moods, and out from real life. Accessing internet makes individuals feel better and lets them coped from their problem [19]. Tolerance shows the need to increase the engagement and involvement in addictive behaviour to build an experience related to initial behavior engagement. In short, individual being online to feel pleasant like what they expect). Withdrawal denotes when the individual low or discontinues their behavior and then resulting in negative physiopsychological impact. Conflict can occur both the interpersonal and intrapersonal problems that resulting a consequence of certain behavior. Individuals with the potential of Internet addiction usage escape their relationships with others for the sake of Internet use and has a potential to lose control in accessing internet. However, it leads to interpersonal conflict.

A number of characteristic in internet addiction describe certain reason of the correlation between social network usage and FOMO among female instagram user. Social media use is associated with negative body image consistently and positively [7]. Female who access instagram as social network excessively tend to compare their own body to others such as influencer or selebgram whom they are adore.

\section{CONCLUSION}

In conclusion, that the higher the level of social media addiction, the higher the level of FOMO on female instagram user. Female students use Instagram more than male students do. Most of their activities are followed artis and celebrities, promote themselves, and even online shopping. This contionous behavior cause addiction in social media especially instagram and cause of FOMO. The limitations of this study are the samples were limited and the distinction between heavy and light users are not informed.

\section{REFERENCES}

[1] Asosiasi Penyelenggara Jasa Internet Indonesia. (2017). infografis Penetrasi dan Perilaku Pengguna Internet Indonesia: Tidak Diterbitkan
[2] Supratman, Lucy Pujasari. (2018). Penggunaan Media Sosial oleh Digital Native. Jurnal Ilmu Komunikasi. 15 (1); 47-60

[3] Mulawarman \& Nurfitri Aldila. (2017). Perilaku Pengguna Media Sosial beserta Implikasinya Ditinjau dari Perspektif Psikologi Sosial Terapan. Buletin Psikologi. 25 (1); 36 - 44

[4] Laksana, Nur Chandra. (13 Maret 2018). Ini Jumlah Total Pengguna Media Sosial di Indonesia. Diperoleh 3 April 2019. Diunduh

dari https://techno.okezone.com/read/2018/03/13/207/1872093/ini jumlah-total-pengguna-media-sosial-di-indonesia

[5] Huang, Yi Tang \& Su, Seng Fang. (2018). Motives for Instagram Use and Topics of Interest among Young Adults. Future Internet. doi:10.3390/fi10080077

[6] Salim, Frensen, Rahardjo, Wahyu, Tanaya, Tanaya, Titah\& Qurani, Rahmah. (2017). Are Self-Presentation of Instagram Users Influenced by Friendship-Contingent Self-Esteem and Fear of Missing Out. Makara Hubs-Asia. 21 (2); 70-82 DOI: 10.7454/mssh.v21i2.3502.

[7] Apodaca, Jocelyn. (2017). "True-self and the uses and gratifications of Instagram among college-aged females. UNLV Theses, Dissertations, Professional Papers, and Capstones. 2936

[8] Franchina, Vittoria dkk (2018). Fear of Missing Out as a Predictor of Problematic Social Media Use and Phubbing Behavior among Flemish Adolescents. Internation journal of environmental research and public health. 1-18.

[9] Reyes, Marc dan Cayubit, Ryan (2018). Fear of missing out and its link with social media and problematic internet use among Filipinos. North American Journal of Psychology. 20 (3); 503-.518

[10] Sahin, Cengiz. (2018). Social Media Addiction Scale - Student Form: The Reliability and Validity Study. TOJET: The Turkish Online Journal of Educational Technology. 17 (1); 169-182

[11] Przybylski, andrew, Murayama, Kou.,DeHaan, Cody.,\& Gladwell, Valerie.(2013). Motivational, emotional, and behavioral correlates of fear of missing out. Computers in Human Behavior. 29; 1841-1848

[12] Yin, F. S., Liu, M. L. \& Lin, C. P. (2015), "Forecasting the continuance intention of social networking sites: Journal of Education and Practice www.iiste.org ISSN 2222-1735 (Paper) ISSN 2222-288X (Online) Vol.8, No.17, 2017 Assessing privacy risk and usefulness of technology", Technological Forecasting and Social Change 99, 267272.

[13] Aquino, C. (2011). Social Networking On-The-Go: U.S. Mobile Social Media Audience Grows 37 Percents in The Past Year. [Online]. Tersedia di: http://www.comscore.com/Press_Events/Press_Release/2013/11/Soci al_Networking_On-The-Go

U.S._Mobile_Social_Media_Audience_Grows_37_Percents_in_The_ Past_Year

[14] Orford, J. (2005). Problem Gambling and Other Behavioral Addictions. [Online]. Tersedia di: http://www.foresight.gov.uk/Brain_science_Addiction_and_Drugs/In dex.htm

[15] Fardouly, Jasmine , Willburger, Brydie K, and Vartanian, Lenny R. (2018). Instagram use and young women's body image concerns and self-objectification: Testing mediational pathways. Journal of New Media and Society. 20 (4) 1380-1395. DOI $/ 10.1177 / 1461444817694499$

[16] Wally, E. \& Koshy, S. 2014, 'The use of Instagram as a marketing tool by Emirati female entrepreneurs: an exploratory study', 29th International Business Research Conference, World Business Institute Australia, Australia, pp. 1-19 Doi

[17] Hermawati, Yessy.,Piyatna, Aquarini.,Adji, Mohamad. (2016). Instagram dan Mitos Kecantikan Perempuan Muslim. Riksa Bahasa. 2(2); 237-245

[18] Griffith, M. (1999). Internet Addiction: Fact or Fiction? Psychologist, 12 (50, 246-250. [Online]. Tersedia di: http://www.academia.edu/429664/Griffiths_M.D. 1999_. Internet_a ddiction_Fact_or_fiction_The_Psychologist_Bulletin_of_the_British _Psychological_Society_12_246-

250?login=\&email_was_taken $=$ true $\& \operatorname{login}=\&$ email_was_taken=true

[19] Young, K \& De Abreu, CN. (2011). Internet Addiction A Handbook and Guide to Evaluation and Treatmen. New Jersey: John Wiley \& Sons, Inc. 